\title{
BANKING MARKET CONCENTRATION AND BANK EFFICIENCY. EVIDENCE FROM SOUTHERN, EASTERN AND CENTRAL EUROPE
}

Sylwester Kozak, Agata Wierzbowska

\section{Abstract}

The importance of the question about the relationship between concentration and efficiency lies in the fact that banks' efficiency affects ability to extend loans and ensure financial stability of the banking sector. The study examines this relationship on the example of 150 banks operating between 2005 and 2019 in 11 EU and 8 non-EU countries from the SECE region. The value of profit efficiency was assessed with the stochastic frontier approach, and next regressed with the banking market concentration and bank specific and macroeconomic explanatory variables. The results for the entire sample as well as for domestic and foreign-owned banks indicate that concentration positively and nonlinearly impacts bank efficiency, both in EU and non-EU countries. Moreover, the size of a bank and income diversification help to improve efficiency of banks in the SECE region. The study shows that banks in SECE countries seem to follow the efficient structure hypothesis.

Keywords: SECE countries, banking market concentration, bank efficiency, panel data.

JEL Classification: D40, G21, L11

\section{INTRODUCTION}

An efficient and stable banking sector has a significant impact both on the pace of economic growth and the access and cost of obtaining loans by the non-financial sector. This issue is particularly important in developing countries, including those located in Southern, Eastern and Central Europe (SECE), where, due to poorly developed financial markets, bank credit is the primary source of financing economic development. One of the most important factors influencing the level of banks' efficiency is the concentration of the banking market. For this reason, the analysis of the relationship between these two variables has been the subject of research since the 1990s (Evanoff and Israilevich 1991; Berger 1995; Molyneux and Forbes 1995; Goldberg and Rai 1996; Akhavein, Berger, and Humphrey 1997; Berger, Hasan, and Zhou 2009; Duygun, Sena, and Shaban 2013; Mesa, Sánchez, and Sobrino 2014; Nițoi and Spulbar 2015; Silva et al. 2016; Peng et al. 2017;
Sylwester Kozak, PhD Hab. (corresponding author) Associate Professor Institute of Economy and Finance Warsaw University of Life Sciences E-mail: sylwester_kozak@sggw.edu.pl Address: Warsaw University of Life Sciences 166 Nowoursynowska Street 02-787 Warszawa, Poland ORCID: 0000-0001-9485-6704

Agata Wierzbowska, PhD

Associate Professor

Graduate School of Economics

Kobe University

E-mail: wierzbowska@econ.kobe-u.ac.jp

ORCID:0000-0001-8641-3217 
Shijaku 2017; Avramidis, Cabolis, and Serfes 2018).

Yet, the results of the studies conducted so far have not provided scholars with a clear answer to the question of how the increased concentration of the banking market affects the efficiency of banks operating in it. Some studies show a positive impact in the form of imposition of more favourable prices and generating higher income (Goldberg and Rai 1996; Maudos and Fernández de Guevara 2007; Williams 2012), and through the reduction of operating costs as well as economies of scale and scope (Berger and Mester 1997; Peristiani 1997; Boyd and de Nicolo 2005). Other blame the banking market concentration for a decline in banks' efficiency and earnings (Delis and Tsionas 2009; Delis and Papanikolaou 2009). They attribute it to the deterioration of the quality of management, an excessive increase in operating costs, weaker monitoring of lending activities, generating losses on irregular loans, or a reduction in the amount of the granted loans. Some studies, on the other hand, show that it is difficult to notice the existence of a relationship between the level of the banking market concentration and efficiency and financial performance of banks (Casu and Girardone 2006; Pasiouras 2008). The slight improvement in banks' efficiency, achieved in more concentrated markets, is often seen as the result of other factors, such as a strict control of interest rates on loans and deposits (Fu and Heffernan 2009), rather than the use of a monopoly rent. Most of the previous studies refer to the banking sectors in the highly industrialized countries of North America and Western Europe, while only a small number of them is dedicated to the developing countries, especially to those located in SECE (Pruteanu-Podpiera, Weill, and Schobert 2008; Chen 2009; Delis 2012; Williams 2012; Efthyvoulou and Yildirim 2014).

The increasing concentration of the banking market recorded in several European Union (EU) countries (NBP 2018) generates motivation to explore how this process impacts banks' efficiency. The effects of the COVID-19 pandemic crisis are likely to amplify consolidation in the banking sector through acquisition of banks experiencing losses resulting, inter alia, from the regional or global recessions. The experience of the financial crisis of 2007-2009 in SECE countries shows that the deterioration of the financial position of parent banks contributes to mergers and acquisitions of several subsidiaries with medium and high shares in the host countries' banking sectors. As a result of the 2007-2009 crisis, some Western European and North American banks, including Allied Irish Banks (AIB), KBC Bank, American International Group (AIG), GE Money, Rabobank, UniCredit, partially or completely withdrew from SECE countries, causing rise in concentration of their banking markets. The significant decline in profitability of the banks in the euro area and SECE, reported by some central banks after the first months of the COVID-19 pandemic (ECB 2020; MNB 2020; NBP 2020; NBS 2020; NBU 2020), increases the likelihood of the acquisitions of banks with growing losses on bad loans, mostly due to the coronavirus pandemic and low interest rates. The rise in the banking market concentration will most likely affect the efficiency of banks' operations and their ability to finance the economy.

This paper fills the gap in the literature on the impact of the banking market concentration as well as some other micro and macroeconomic factors on the banks' efficiency in SECE countries, which have rarely been analysed. The conclusions concern the following areas: (1) assessment and comparison of the banking sector efficiency, and the impact of: (2a) the banking market structure, $(2 b)$ individual characteristics of the bank, i.e., income diversification, profitability and capital adequacy, (2c) external factors, i.e., the economic growth, the inflation and the volume of credit granted to the private sector, on the efficiency of banks. The analysis has been carried out for the entire region, for groups of EU and non-EU countries, and separately for banks controlled by domestic and foreign investors and has allowed a more precise identification of the relationship between the concentration and the banks' efficiency. Following Tabak, Fazio, and Cajueiro (2012), nonlinearity in this relationship is tested, expecting that it depends on the level of concentration.

The annual data from 150 banks operating between 2005 and 2019 were obtained from the S\&P Global Market Intelligence. The data on banking market concentration was sourced from ECB (Statistical Data Warehouse) and central banks of SECE countries. Finally, the macroeconomic data was gathered from the World Bank.

The rest of this paper is divided into five sections. Section 2 presents the literature review related to the topic. Section 3 and section 4 present the data on the SECE banks and the methodology respectively. Section 5 comments on the empirical results of the study. Section 6 is dedicated to conclusion and discussion on the outcomes of the study.

\section{LITERATURE REVIEW}

Estimating the optimal concentration level for the efficient and stable functioning of the banking sector is an important issue for researchers and regulators. This is, inter alia, due to the existence of links between the market concentration and the prevailing competition, 
as well as the efficiency and profitability of banks' operations. The existing studies do not precisely indicate how the structure of the banking market impacts the performance of banks. The available literature recognizes three hypotheses that describe this relationship: the quiet life hypothesis (QLH), the efficient structure hypothesis $(\mathrm{ESH})$ and the information generation hypothesis (IGH). The QLH was proposed by Hicks (1935), who noted that, due to market power, large companies do not feel strong competitive pressure. They do not make enough efforts to improve the quality of products and business management, which, in turn, leads to a drop in efficiency. This hypothesis is in line with the structure conduct performance (SCP) paradigm, which indicates that high market concentration and market power motivate banks to set favourable prices and achieve higher and extraordinary income. Rhoades and Rutz (1982), Hannan (1991), Berger and Hannan (1998) were the first scholars to test this hypothesis in the banking sector. They proved that, in the short term, banks with the significant market share raise prices and generate increased profits. Yet, in the long run, their improper loans monitoring and excessive operating costs lead to a drop in their efficiency and competitiveness. In subsequent years, these findings were confirmed by Koetter and Vins (2008), Kirkpatrick, Murinde, and Tefula (2008), Delis and Tsionas (2009), Coccorese and Pellecchia (2010), and Asongu and Odhiambo (2018), among others.

The ESH, formulated by Demsetz (1973), assumes that more effective entities take over less effective competitors and then, thanks to the use of economies of scale and scope, reduce operating costs, diversify the product offer and increase profits. Thus, they obtain favourable conditions for taking over other less efficient competitors. Firstly, this process leads to an increase in the concentration of the market, and, secondly, it improves efficiency of enterprises operating in it. In the banking sector, the ESH was confirmed by the research done by Smirlock (1985) on the US banks and also by Goldberg and Rai (1996), Maudos and Fernández de Guevara (2007) and Williams (2012) on the European, North- and South-American banking sectors. The ESH is consistent with the relative market power (RMP) paradigm, which assumes that larger entities, due to the use of economies of scale and scope, have the capacity to reduce operating costs and to broaden diversification of the delivered products, and hence increase their efficiency. Such activities can be carried out by banks regardless of the level of the banking market concentration (Mirzaei, Moore, and Liu 2013; Andries and Capraru 2014).

The IGH was formulated for the banking sector, for instance by Marquez (2002). It points to a negative relationship between competition and efficiency and notes that banks place more emphasis on quantity rather than quality of assets in order to gain a greater market share. The more competitive the banking market becomes, the more customers are prompted to switch between banks, which decreases banks' motivation to collect additional information about their clients. As a result, the quality of loan portfolio deteriorates, and so does the efficiency of banks' operations. Conversely, greater concentration of the banking market and less aggressive competition motivate banks to invest in gathering soft information on customers and in credit monitoring measures. This contributes to the improvement of the quality of the portfolio and efficiency of operations (Fungácová, Shamshur, and Weill 2017).

The research on the relationship between concentration and efficiency in the banking sectors in SECE countries is rather limited. Efthyvoulou and Yildirim (2014) found a significant relationship between market power and banks' performance in Central and Eastern Europe (CEE) in the pre-crisis and post-crisis periods. In addition, they stated that the magnitude of dependence of competitive conditions on banks' performance varies significantly across countries and types of ownership. Fries and Taci (2005) tested banks in 15 Eastern European countries and came to the conclusion that foreign-owned and privatised banks are more cost efficient than their state-owned competitors. Fang, Hasan, and Marton (2011) assessed the efficiency of banks in six South-Eastern European countries between 1998 and 2008, and discovered that bank's market power positively affects both its cost and profit efficiency. The efficiency improves due to the progress in banking regulatory reforms, privatisation and restructuring in corporate governance. On the other hand, Cifter (2015), who studied banking sectors in ten CEE countries, observed that the relationship between concentration and stability is ambiguous and that the concentration may both improve and deteriorate the quality of banks' loan portfolio.

\section{SECE BANKING DATA}

This study uses annual data from 150 banks operating between 2005 and 2019 in 19 SECE countries (1756 observations), including 11 EU (i.e., Bulgaria, Croatia, Czechia, Estonia, Hungary, Latvia, Lithuania, Poland, Romania, Slovakia and Slovenia - 992 observations) and 8 non-EU countries (i.e., Belarus, Bosnia and Herzegovina, Moldova, Montenegro, Russia, Serbia, Ukraine - 764 observations). Development banks and banks with less than three-year-long observations were 
excluded from the sample. Balance sheet, profit and loss account data, as well as the values of capital ratios (Tier1) and bank profitability (ROA, ROE, C/I) were obtained from the S\&P Global Market Intelligence. These values were used in the study on the relationship between bank efficiency and banking market concentration as variables controlling banks' characteristics. Two indicators were adapted as the concentration measures: the share of top five banks in total assets of the country's banking sector (CR5) and the sum of squared shares of all banks (based on assets) in the country $(\mathrm{HHI})$ (see Table A1). The data on concentration in EU countries were obtained from the ECB Statistical Data Warehouse, and for non-EU countries from their central banks. Following most research on efficiency, two macroeconomic variables were applied to control for the state of the bank's external environment: GDP growth and inflation rate. The ratio of credit granted to the private sector to GDP (Cr.GDP) controls for the state of development of the banking sector.
The values of operating income, gross loans and other earning assets are significantly related to the size of the national economies, what could be noticed in the case of the Russian Federation (Russia), Poland and Czechia, and on the other hand in Bosnia and Herzegovina, Moldova, Montenegro or North Macedonia (see Table 1). The fact that the highest prices of physical capital occur in Latvia, Lithuania, and Czechia and the lowest in Belarus, Ukraine, and Bosnia and Herzegovina may imply that, in more developed countries, physical capital consists of more technologically advanced devices for which higher depreciation charges are applied. Prices of labour in SECE banks are relatively homogeneous. The highest prices of funds in Belarusian, Russian and Ukrainian banks, and the lowest in the euro area countries indicate that they are mainly determined by the level of interest rates in force in individual countries. The distributions of control variables specific to individual banks, i.e., bank size, capitalization or profitability are relatively

Table 1. The average values of variables used in the study

\begin{tabular}{|c|c|c|c|c|c|c|c|c|c|c|c|c|c|c|c|c|c|c|}
\hline & PROF & Q1 & Q2 & W1 & W2 & W3 & Size & Eq.TA & HHI & CR5 & Tier 1 & ROA & ROE & $\mathrm{Cl}$ & Diver & GDP.gr & Infl & Cr.GDP \\
\hline BY & 391 & 3879 & 1837 & 0.09 & 0.02 & 0.08 & 15.2 & 16.5 & 0.20 & 80.9 & 18.1 & 1.0 & 7.1 & 50.8 & 0.5 & 3.7 & 21.4 & 28.8 \\
\hline BA & 30 & 421 & 198.8 & 0.09 & 0.02 & 0.02 & 12.8 & 13.7 & 0.11 & 61.6 & 15.2 & 0.7 & 6.2 & 69.4 & 0.5 & .7 & 2.3 & 59.5 \\
\hline BG & 163 & 2180 & 968.8 & 0.15 & 0.01 & 0.03 & 14.6 & 11.3 & 0.08 & 55.3 & 15.1 & 0.4 & 10.7 & 55.9 & 0.5 & 3.1 & 4.1 & 57.3 \\
\hline$H R$ & 161 & 2482 & 1174 & 0.15 & 0.01 & 0.03 & 13.9 & 12.7 & 0.14 & 70.8 & 17.8 & 0.1 & -3.1 & 67.7 & 0.5 & 1.2 & 1.9 & 62.8 \\
\hline & 676 & 10300 & 7491 & 0.22 & 0.01 & 0.01 & 16.2 & 9.6 & 0.10 & 63.2 & 19.0 & 1.3 & 14.2 & 45.1 & 0.4 & 2.6 & 1.5 & 46.2 \\
\hline FF & 177 & 4083 & 1349 & 0.28 & 0.01 & 0.01 & 14.7 & 11.8 & 0.28 & 92.1 & 24.5 & 1.2 & 8.1 & 60.4 & 0.5 & 29 & 4.4 & 73.8 \\
\hline HU & 530 & 6190 & 2996 & 0.18 & 0.01 & 0.04 & 15.7 & 8.8 & 0.08 & 52.4 & 13.5 & 0.1 & -1.8 & 63.6 & 0.5 & .0 & 3.4 & 46.0 \\
\hline LV & 152 & 2972 & 1192 & 0.30 & 0.01 & 0.01 & 15.2 & 10.7 & 0.12 & 68.4 & 16.8 & 1.0 & 8.8 & 54.2 & 0.5 & 2.7 & 4.7 & 55.4 \\
\hline & 112 & 2491 & 978 & 0.11 & 0.01 & 0.02 & 14.8 & 10.0 & 0.19 & 84.7 & 13.8 & 0.5 & 5.0 & 60.3 & 0.5 & 3.2 & 3.6 & 44.4 \\
\hline IV & 26 & 204 & 190 & 0.14 & 0.02 & 0.05 & 12.6 & 17.4 & 0.17 & 79.4 & 35.3 & 1.8 & 11.7 & 58.8 & 0.6 & 4 & 9.3 & 28.5 \\
\hline E & 37 & 466 & 212 & 0.12 & 0.02 & 0.02 & 13.4 & 11.7 & 0.14 & 72.4 & 17.1 & -0.1 & -0.5 & 67.3 & 0.5 & 27 & 4.1 & 55.3 \\
\hline MK & 34 & 450 & 217 & 0.11 & 0.02 & 0.02 & 12.9 & 13.4 & 0.15 & 75.1 & 15.9 & 0.7 & 6.9 & 69.2 & 0.5 & 3. & 3.0 & 49.8 \\
\hline DI & 707 & 11000 & 4351 & 0.19 & 0.01 & 0.02 & 16.1 & 10.8 & 0.06 & 46.5 & 13.1 & 1.1 & 9.4 & 62.0 & 0.5 & 4.0 & 2.0 & 47.1 \\
\hline DO & 377 & 4207 & 2261 & 0.14 & 0.02 & 0.03 & 15.4 & 10.1 & 0.09 & 56.8 & 14.2 & 0.6 & 5.5 & 60.9 & 0. & 3 & 6.5 & 31.2 \\
\hline RU & 1151 & 13700 & 4834 & 0.12 & 0.02 & 0.07 & 15.3 & 13.6 & 0.10 & 50.0 & 15.0 & 0.8 & 4.7 & 54.3 & 0.3 & 2.6 & 10.6 & 45.1 \\
\hline 10 & 75 & 782 & 468 & 0.12 & 0.01 & 0.03 & 13.6 & 20.8 & 0.07 & 74.9 & 21.9 & 1.5 & 6.7 & 59.6 & .0.4 & 2.0 & 6.1 & 39.1 \\
\hline SK & 264 & 4867 & 1889 & 0.16 & 0.01 & 0.01 & 15.1 & 17.5 & 0.12 & 71.5 & 15.6 & 0.5 & 4.3 & 65.7 & 0.4 & 3.7 & 1.1 & 49.0 \\
\hline 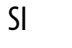 & 252 & 4498 & 2655 & 0.10 & 0.01 & 0.02 & 15.5 & 10.4 & 0.12 & 59.7 & 15.6 & -0.5 & -12.6 & 57.0 & 0.5 & 2.0 & 1.7 & 62.4 \\
\hline$J^{\prime}$ & 212 & 1961 & 183 & 0.09 & 0.02 & 0.07 & 14.0 & 12.8 & 0.09 & 55.5 & 14.7 & -2.9 & -15.8 & 74.8 & 0. & 0.1 & 17.4 & 65.8 \\
\hline SECE & 537 & 6943 & 2845 & 0.15 & 0.01 & 0.04 & 14.9 & 12.6 & 0.11 & 59.8 & 16.1 & 0.5 & 3.6 & 60.2 & 0.4 & 2.7 & 6.6 & 49.2 \\
\hline
\end{tabular}

Note: Belarus - BY, Bosnia and Herzegovina - BA, Bulgaria - BG, Croatia - HR, Czech Republic - CZ, Estonia - EE, Hungary - HU, Latvia - LV, Lithuania - LT, Moldova - MD, North Macedonia - ME, Montenegro - MK, Poland - PL, Romania - RO, Russia - RU, Serbia - RS, Slovakia - SK, Slovenia - SI, SECE - Southern, Eastern and Central European countries.

Source: Authors' estimations based on the S\&P GMI data. 
strongly diversified throughout SECE countries.

In turn, the distribution of the income diversification, assessed as one minus the sum of the squared shares of individual types of the banking income, may be significantly influenced by the levels of interest rates and the development of the country's financial system. The least diversified income is generated by banks in countries with high level of interest rates, which concentrate their income on lending and deposit activities (Russia, Ukraine). The size of the banking sector and country's economy as well as the low number of operating banks are significant reasons why banking markets are most concentrated in Estonia, Croatia, Lithuania, Moldova, North Macedonia and Montenegro and the least in Poland and Russia. The values of macroeconomic variables are significantly diversified, with the most favourable values recorded by larger EU economies, i.e., Czechia, Poland, and Slovenia. The values of elements of the correlation matrix of the variables used as factors influencing profit efficiency of banks are low which implies the lack of significant collinearity between the explanatory variables (see Table A2).

\section{METHODOLOGY}

To determine the value of profit efficiency of individual banks, the stochastic frontier approach (SFA) was applied (Fries and Taci 2005; Yildirim and Philippatos 2007; Asaftei and Kumbhakar 2008; Weill 2009; Andries and Ursu 2016). Assuming that the bank operates in line with the financial intermediation model, two output products were used: (1) gross loans (Q1) and (2) other financial assets (Q2), as well as three input products: (1) the bank's physical capital, the price of which is measured by the ratio of depreciation charges to fixed assets (W1), (2) labour - the ratio of labour costs to assets (W2), and (3) funds - the ratio of interest expenses to financial liabilities (W3). Bank's profit (Prof) was represented by the operating income which covers the income generated from all types of core banking activities: net interest income, net fees and commissions and income from financial operations. Following Berger and Mester (1997) and Andries and Ursu (2016) the leverage ratio (Eq.TA) was included to control for differences in risk preferences across banks. To impose linear homogeneity restrictions, the dependent variable (Prof) and all input prices were normalized by the price of funds (W3). Finally, time dummy $(\mathrm{T})$ in both linear and quadratic form was introduced to allow for technological and other timespecific changes (Lensink, Meesters, and Naaborg 2008; Lozano-Vivas and Pasiouras 2010; Andries and Ursu 2016).

The estimation was conducted with the use of true fixed-effects model by Greene (2005). This approach adopts maximum-likelihood dummy variable as estimation technique and allows estimating time-varying inefficiency that is disentangled from bank-specific time-invariant unobserved heterogeneity. Following Parmeter and Kumbhakar (2014), the assessed translogarithmic frontier curve representing the bank profit is given by the following formula:

$$
\begin{aligned}
& \ln \frac{\text { Prof }_{i t}}{W 3_{i t}}=b_{0}+b_{1} \ln \left(\frac{W 1_{i t}}{W 3_{i t}}\right)+b_{2} \ln \left(\frac{W 2_{i t}}{W 3_{i t}}\right)+b_{3} \ln \left(Q 1_{i t}\right)+b_{4} \ln \left(Q 2_{i t}\right)+ \\
& b_{5} \frac{1}{2}\left(\ln \left(Q 1_{i t}\right)\right)^{2}+b_{6} \frac{1}{2}\left(\ln \left(Q 2_{i t}\right)\right)^{2}+b_{7} \ln \left(Q 1_{i t}\right) \ln \left(Q 2_{i t}\right)+b_{8} \frac{1}{2}\left(\ln \left(\frac{W 1_{i t}}{W 3_{i t}}\right)\right)^{2}+ \\
& b_{9} \frac{1}{2}\left(\ln \left(\frac{W 2_{i t}}{W 3_{i t}}\right)\right)^{2}+b_{10} \ln \left(\frac{W 1_{i t}}{W 3_{i t}}\right) \ln \left(\frac{W 2_{i t}}{W 3_{i t}}\right)+b_{11} \ln \left(\frac{W 1_{i t}}{W 3_{i t}}\right) \ln \left(Q 1_{i t}\right)+ \\
& b_{12} \ln \left(\frac{W 1_{i t}}{W 3_{i t}}\right) \ln \left(Q 2_{i t}\right)+b_{13} \ln \left(\frac{W 2_{i t}}{W 3_{i t}}\right) \ln \left(Q 1_{i t}\right)+b_{14} \ln \left(\frac{W 2_{i t}}{W 3_{i t}}\right) \ln \left(Q 2_{i t}\right)+ \\
& b_{15} \frac{1}{2} T_{t}^{2}+b_{16} \ln \left(\frac{W 1_{i t}}{W 3_{i t}}\right) T_{t}+b_{17} \ln \left(\frac{W 2_{i t}}{W 3_{i t}}\right) T_{t}+b_{18} \ln \left(Q 1_{i t}\right) T_{t}+b_{19} \ln \left(Q 2_{i t}\right) T_{t}+ \\
& b_{20} \ln \left(E q_{-} T A_{i t}\right)+b_{21} \ln \left(\frac{W 1_{i t}}{W 3_{i t}}\right) \ln \left(E q_{-} T A_{i t}\right)+b_{22} \ln \left(\frac{W 2_{i t}}{W 3_{i t}}\right) \ln \left(E q_{-} T A_{i t}\right)+ \\
& b_{23} \ln \left(Q 1_{i t}\right) \ln \left(E q_{-} T A_{i t}\right)+b_{24} \ln \left(Q 2_{i t}\right) \ln \left(E q_{-} T A_{i t}\right)+b_{25} \ln \left(E q_{-} T A_{i t}\right) T_{t}+ \\
& v_{i t}+u_{i t}
\end{aligned}
$$

where, $\mathrm{u}_{\mathrm{it}}$ are individual bank profit inefficiency effects, which is equivalent to profit efficiency given with the equation $P E_{i t}=\exp \left(-u_{i t}\right)$.

In the next step, the relationship between the estimated bank profit efficiency $P E_{i t}$ and the market concentration across the SECE banking sectors was investigated. For this purpose, $P E_{i t}$ was regressed with the market concentration measures and range of explanatory variables describing macroeconomic situation and the banking sector of each country, as well as bank-specific characteristics according to the following formula: 


$$
\begin{gathered}
\text { PE }_{i t}=\delta_{1} \text { Concentration }_{j t}+\delta_{2} \text { Concentration }_{j t}^{2}+\delta_{3} \text { Size }_{i t}+\delta_{4} \text { GDPgrowt }_{j t-1} \\
+\delta_{5} \text { Infl }_{j t-1}+\delta_{6} \text { Credit_GDP }_{j t-1}+\delta_{7} \text { bank_char }_{i t}+\varepsilon_{i t}
\end{gathered}
$$

for country $j$, bank $i$, and time $t$.

The equation (2) was estimated with random-effects Tobit model. Dependent variable $P E_{i t}$ is bound between zero and one, hence Tobit model is a better choice of estimation method than OLS. Moreover, Tobit models are more suitable for models where the dependent variable is derived from a first-stage regression (Ariss 2010). Likelihood-ratio tests comparing the panel estimator with the pooled Tobit model indicate that panel-level variance components are important, therefore panel estimation is appropriate in our case.

The market concentration could affect bank efficiency both positively and negatively. The first option would prove the ES hypothesis, which assumes that more efficient banks take over their competitors and increase the market concentration (Goldberg and Rai 1996; Maudos and Fernández de Guevara 2007; Williams 2012). On the other hand, the second option would prove the QL hypothesis, which assumes that increase in concentration weakens banks' motivation to collect data on customers and to monitor borrowers, which, in turn, leads to a drop in efficiency (Rhoades and Rutz 1982; Hannan 1991; Berger and Hannan 1998). Following the literature (e.g., Tabak, Fazio, and Cajueiro 2012), a quadratic term of concentration variable was used to account for potential nonlinear relation between concentration and efficiency.

Economic literature points to the positive impact of the profitability of a bank on efficiency. Generating higher profits from total assets or total equity, and reducing operating costs increase the bank's efficiency. For this reason, it should be expected that the profitability of banks' operations, measured with ROA and ROE ratios, as well as C/I cost effectiveness are conducive to their efficiency (Loukoianova 2008). The studies conducted so far have indicated diversified impact of capital endowment on banks' efficiency. On the one hand, a higher share of own capital in funding increases the level of financial stability and creates more favourable conditions for conducting banking activities (Kasman and Yildirim 2006), but on the other, it raises the weighted average cost of capital and weakens the profitability of invested capitals (Altunbas et al. 2007). Pasiouras (2008), for instance, did not find a statistically significant impact of capital endowment on efficiency of banks. In this study, we assume positive or no impact of capital ratios on banks' efficiency.

The studies conducted so far have stated that the diversification of income sources has either positive or negative impact on the efficiency of banks.
On the one hand, additional sources of income improve earnings and efficiency of the bank as well as increase its market value (Vander Vennet 2002; Baele, De Jonghe, and Vander Vennet 2007; Elsas, Hackethal, and Holzhauser 2010). However, excessive widening of bank's offer reduces its specialization and lowers management efficiency (Laeven and Levine 2007; Schmid and Walter 2009). In the study we apply the diversification measure as one minus the sum of the squared shares of three types of income (Curi, LozanoVivas, and Zelenyuk 2015; Saghi-Zedek 2016). In the literature, the most frequently used measure is the net non-interest income over operating income ratio, which results from the lack of detailed data on noninterest income. Yet, it limits the ability to assess the impact of profits on financial operations, which are an important part of banks' non-interest income in some EU countries.

It can be expected that the high dynamics of economic development, expressed by the GDP growth rate, enables banks to generate higher profits and improve profit efficiency (Yildirim and Philippatos 2007). However, too rapid economic growth may induce banks to extend excessive amount of credit preventing proper monitoring borrowers and operating costs, and leading to deterioration in the quality of loan portfolio and bank efficiency (Maudos et al. 2002; Pasiouras 2008). In turn, the impact of inflation on efficiency may be most likely negative (Pasiouras 2008).

\section{RESULTS AND DISCUSSION}

In the first stage of the study, banks' profit efficiency scores $P E_{i t}$ were estimated using the trans-logarithmic equation (1). The results show a diversified structure of banks' efficiency in SECE countries (see Table 2). The most efficient banks operate in Estonia (87.3\%), North Macedonia (86.9\%), Bosnia and Herzegovina (86.5\%) and Croatia (86.4\%), and the least in Ukraine (77\%), Bulgaria (77.7\%) and Belarus (78.1\%). The advantage of Estonia in terms of efficiency of banks is particularly evident after 2011, when the average reached 90\% and exceeded by several percentage points banking sectors in other countries. The average efficiency in the SECE region equals to $82.7 \%$. During the entire period under analysis, SECE banks operated with a varying degree of efficiency, which decreased in the periods of macroeconomic turbulences between 2008 
Table 2. Average profit efficiency scores (in \%)

\begin{tabular}{rllllllllllllllllllll}
\hline Year & BY & BA & BG & HR & CZ & EE & HU & LV & LT & MD & ME & MK & PL & RO & RU & RS & SK & SI & UA SECE \\
\hline 05 & & 83 & 76 & 92 & 86 & & 89 & 94 & 93 & 80 & & 96 & 80 & 87 & 85 & & & & 85 & 85 \\
06 & & 82 & 80 & 90 & 87 & & 84 & 89 & 91 & 93 & 91 & 82 & 83 & 85 & 83 & 89 & & 91 & 85 & 85 \\
07 & 82 & 81 & 89 & 81 & 89 & 73 & 83 & 86 & 85 & 90 & 93 & 87 & 87 & 85 & 78 & 88 & 88 & 90 & 84 & 83 \\
08 & 74 & 78 & 83 & 82 & 82 & 73 & 81 & 76 & 76 & 90 & 92 & 83 & 85 & 80 & 75 & 88 & 87 & 80 & 93 & 81 \\
09 & 88 & 80 & 81 & 81 & 94 & & 84 & 88 & 71 & 86 & 92 & 81 & 78 & 84 & 89 & 83 & 85 & 89 & 78 & 84 \\
10 & 83 & 88 & 80 & 88 & 93 & 72 & 88 & 62 & 72 & 94 & 85 & 74 & 79 & 91 & 82 & 84 & 90 & 92 & 71 & 82 \\
11 & 15 & 90 & 68 & 90 & 86 & 80 & 90 & 83 & 76 & 87 & 78 & 69 & 91 & 88 & 77 & 84 & 89 & 88 & 79 & 81 \\
12 & 88 & 88 & 60 & 86 & 88 & 86 & 77 & 88 & 89 & 82 & 78 & 67 & 86 & 85 & 80 & 87 & 90 & 91 & 47 & 78 \\
13 & 68 & 86 & 64 & 87 & 83 & 91 & 84 & 93 & 91 & 71 & 89 & 78 & 86 & 87 & 81 & 88 & 91 & 37 & 71 & 80 \\
14 & 66 & 87 & 78 & 87 & 89 & 92 & 87 & 90 & 93 & 83 & 91 & 80 & 87 & 88 & 79 & 85 & 92 & 75 & 86 & 84 \\
15 & 90 & 85 & 85 & 81 & 89 & 90 & 80 & 90 & 88 & 95 & 92 & 86 & 84 & 87 & 74 & 88 & 90 & 90 & 78 & 82 \\
16 & 94 & 91 & 91 & 90 & 84 & 90 & 87 & 88 & 92 & 92 & 90 & 91 & 85 & 90 & 85 & 90 & 85 & 84 & 78 & 87 \\
17 & 94 & 92 & 87 & 91 & 81 & 91 & 83 & 89 & 85 & 85 & 91 & 92 & 89 & 87 & 82 & 92 & 83 & 79 & 88 & 86 \\
18 & 90 & 90 & 83 & 88 & 81 & 91 & 84 & 84 & 88 & 80 & 90 & 87 & 83 & 86 & 78 & 91 & 79 & 81 & 88 & 83 \\
19 & 83 & 91 & 79 & 86 & 79 & 89 & 87 & 80 & 88 & 70 & 68 & 91 & 83 & 86 & 76 & 89 & 71 & 78 & 77 & 81 \\
Av & 78 & 87 & 78 & 86 & 86 & 87 & 84 & 85 & 83 & 84 & 87 & 81 & 84 & 86 & 80 & 88 & 87 & 80 & 77 & 83 \\
\hline
\end{tabular}

Note: BY - Belarus, BA - Bosnia and Herzegovina, BG - Bulgaria, HR - Croatia, CZ - Czechia, EE - Estonia, HU - Hungary, LV Latvia LT - Lithuania, MD - Moldova, ME - North Macedonia, MK - Montenegro, PL - Poland, RO - Romania, RU - Russia, RS - Serbia, SK - Slovakia, SI - Slovenia, SECE - Southern, Eastern and Central European countries, Av - average.

Source: Authors' estimations based on the S\&P GMI data.

and 2009 or between 2012 and 2013 and returned to relatively high values outside these periods.

In the second stage of the study, the impact of banking market concentration on banks' profit efficiency scores $P E_{i t}$ was explored, controlling for the influence of some macroeconomic variables and bank characteristics. The results of this estimation confirm the assumption about the existence of a significant impact of the market structure on the bank profit efficiency (see Table 3). The concentration, in general, creates favourable conditions for banks to increase their profit efficiency. The positive signs of the coefficients of concentration and the negative of its square signify that this relationship is in the shape of an inverted parabola. This means that an increase in concentration, in the case of low and high concentrated markets, provides a smaller positive impulse for the improvement of banks' efficiency, contrary to the case of moderately concentrated markets. The maximum point of the parabola corresponds to the optimal concentration level and maximum bank efficiency, which can be derived from the zero value of the first derivative of the profit efficiency with respect to the concentration (see Table 3).

Table 3. Relationship between profit efficiency scores, concentration, and explanatory variables

\begin{tabular}{|c|c|c|c|c|c|c|c|c|c|}
\hline \multirow[b]{2}{*}{ Variable } & \multicolumn{3}{|c|}{ Model 1a } & \multicolumn{3}{|c|}{ Model 1b } & \multicolumn{3}{|c|}{ Model 2a } \\
\hline & EU & Non-EU & SECE & EU & Non-EU & SECE & EU & Non-EU & SECE \\
\hline I.GDPgrh & $\begin{array}{l}-0.0017 \\
(0.0010)\end{array}$ & $\begin{array}{l}0.0032 b \\
(0.0013)\end{array}$ & $\begin{array}{c}0.0008 \\
(0.0008)\end{array}$ & $\begin{array}{l}-0.0017 \\
(0.0011)\end{array}$ & $\begin{array}{l}0.0036 b \\
(0.0014)\end{array}$ & $\begin{array}{c}0.0006 \\
(0.0008)\end{array}$ & $\begin{array}{l}-0.0015 \\
(0.0011)\end{array}$ & $\begin{array}{l}0.0031 b \\
(0.0013)\end{array}$ & $\begin{array}{c}0.0008 \\
(0.0008)\end{array}$ \\
\hline I.Infl & $\begin{array}{c}-0.0031 b \\
(0.0012)\end{array}$ & $\begin{array}{c}-0.0004 \\
(0.0006)\end{array}$ & $\begin{array}{l}-0.0006 \\
(0.0005)\end{array}$ & $\begin{array}{c}-0.0024 c \\
(0.0013)\end{array}$ & $\begin{array}{c}0.0001 \\
(0.0007)\end{array}$ & $\begin{array}{l}-0.0001 \\
(0.0005)\end{array}$ & $\begin{array}{c}-0.0026 b \\
(0.0013)\end{array}$ & $\begin{array}{l}-0.0004 \\
(0.0006)\end{array}$ & $\begin{array}{c}-0.0005 \\
(0.0005)\end{array}$ \\
\hline I.Cr.GDP & $\begin{array}{c}0.0002 \\
(0.0003)\end{array}$ & $\begin{array}{c}0.0002 \\
(0.0005)\end{array}$ & $\begin{array}{c}0.0004 \\
(0.0003)\end{array}$ & $\begin{array}{c}0.0006 \\
(0.0003)\end{array}$ & $\begin{array}{c}0.0012 \\
(0.0007)\end{array}$ & $\begin{array}{l}0.0010 \mathrm{a} \\
(0.0003)\end{array}$ & $\begin{array}{c}0.0000 \\
(0.0003)\end{array}$ & $\begin{array}{c}0.0003 \\
(0.0005)\end{array}$ & $\begin{array}{c}0.0003 \\
(0.0003)\end{array}$ \\
\hline CR5 & $\begin{array}{l}0.0135 a \\
(0.0017)\end{array}$ & $\begin{array}{l}0.0248 a \\
(0.0024)\end{array}$ & $\begin{array}{c}0.0169 a \\
(0.0013)\end{array}$ & & & & $\begin{array}{l}0.0128 a \\
(0.0017)\end{array}$ & $\begin{array}{l}0.0244 a \\
(0.0024)\end{array}$ & $\begin{array}{l}0.0168 a \\
(0.0013)\end{array}$ \\
\hline
\end{tabular}


Table 3. Continued

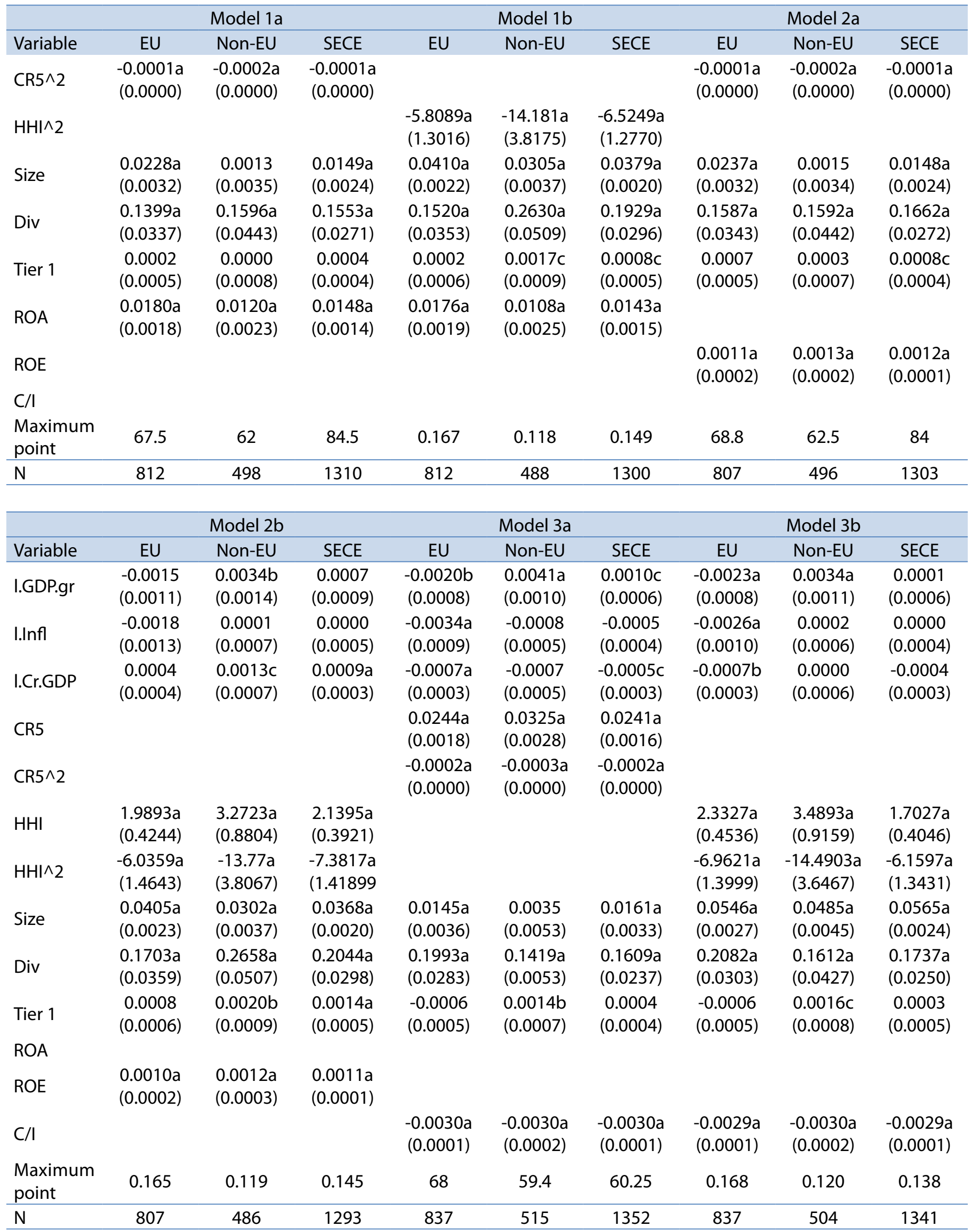

Note: $a, b$ and c represent $1 \%, 5 \%$ and $10 \%$ significance levels, respectively.

Source: Authors' estimations based on the S\&P GMI data. 
The average values of maximum points for $\mathrm{EU}$ countries obtained from models 1,2 and 3 are equal to $68.1 \%$ for CR5 and 0.167 for $\mathrm{HHI}$, and for non-EU countries $61.3 \%$ and 0.119 respectively. On the other hand, the average values of CR5 and HHI for the period between 2005 and 2019 are equal to $62.4 \%$ and 0.113 in the EU, whereas outside the EU they reach $56.8 \%$ and 0.098 respectively. This means that there is still room for consolidation in the banking sectors of both regions, which may result in an increase in profit efficiency.

Figure 1 illustrates the relationship between the level of banking market concentration and efficiency, based on the estimation results obtained from models 1,2 and 3 . Only statistically significant explanatory variables were used to determine the efficiency level and their values. With the exception of the CR5 and $\mathrm{HHI}$ variables, they were equal to sample averages for the period between 2005 and 2019 both for the EU and non-EU countries.

The average concentration indices for the period between 2005 and 2019 are lower than their values for which the efficiency reaches its maximum (for both groups of countries and for the three models analysed). It means that a further increase in concentration, which might come from the takeover of a bank hit by the pandemic crisis, could still improve the banking sector efficiency. Such positive impact of the banking sector structure on banks' efficiency is also confirmed by the positive values of coefficients for the bank size, which is especially visible in EU countries. Consequently, a potential banks' consolidation might lead to an increase in the efficiency of the entire banking sector. This confirms the ES hypothesis.

The impact of banking market concentration on banks' efficiency might vary depending on the ownership status. In general, foreign-controlled banks (foreign banks) in developing countries are considered to be both better managed and technologically equipped than domestic-controlled banks (domestic banks), and thus achieve higher profit efficiency and a stronger competitive position. In order to check this relationship, models $1 \mathrm{a}, 2 \mathrm{a}$ and $3 \mathrm{a}$, described in Table 3 , were estimated for two groups of banks: domestic and foreign. The results show that the concentration of the banking market influences the efficiency of domestic and foreign banks in a similar way (see Table 4). The coefficients for the concentration measures in the first and second powers have the same signs and similar values for both domestic and foreign banks which indicates that there is no significant difference in the response of both groups of banks to changes in the concentration of the country's banking market. One of the reasons for this similarity might be the fact that

Figure 1. Relationship between banks' efficiency and concentration of the banking market
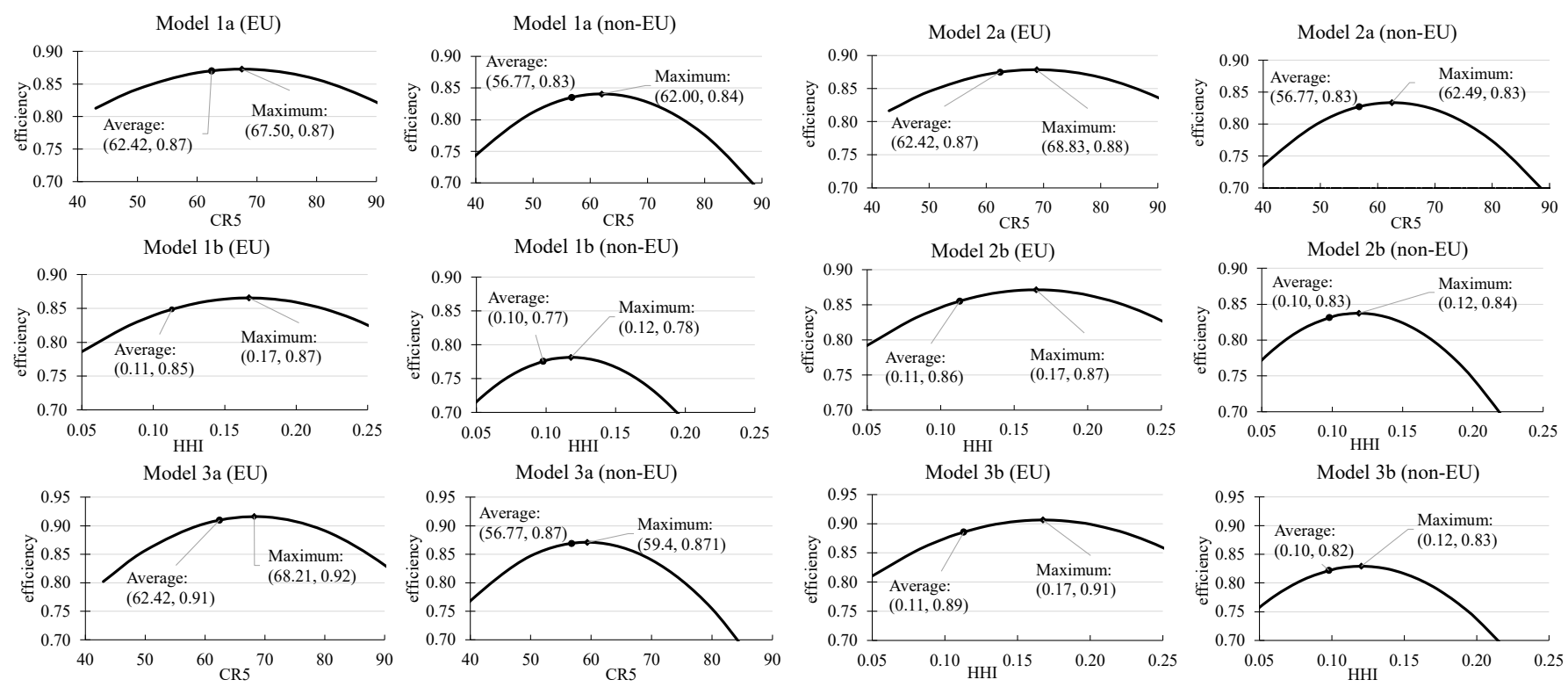

Notes: Relation between concentration and efficiency, based on estimation results from model 1, 2 and 3; Average - the average CR5 / HHI value for each group of countries in 2005-2019 and the fitted-value efficiency, Maximum - CR5 / HHI value related to the maximum efficiency value and the fitted-value maximum efficiency.

Source: Authors' estimations. 
Table 4. Relationship between profit efficiency scores and concentration for domestic and foreign banks

\begin{tabular}{|c|c|c|c|c|c|c|}
\hline \multirow[b]{2}{*}{ Variable } & \multicolumn{2}{|c|}{ Model 1a } & \multicolumn{2}{|c|}{ Model 2a } & \multicolumn{2}{|c|}{ Model 3a } \\
\hline & Domestic & Foreign & Domestic & Foreign & Domestic & Foreign \\
\hline I.GDPgrh & $\begin{array}{l}0.0033 b \\
(0.0013)\end{array}$ & $\begin{array}{c}-0.0019 b \\
(0.0009)\end{array}$ & $\begin{array}{l}0.0032 b \\
(0.0013)\end{array}$ & $\begin{array}{c}-0.0021 b \\
(0.0009)\end{array}$ & $\begin{array}{l}0.0035 a \\
(0.0010)\end{array}$ & $\begin{array}{c}-0.0017 b \\
(0.0007)\end{array}$ \\
\hline I.Infl & $\begin{array}{l}-0.0010 \\
(0.0007)\end{array}$ & $\begin{array}{c}0.0001 \\
(0.0006)\end{array}$ & $\begin{array}{l}-0.0009 \\
(0.0007)\end{array}$ & $\begin{array}{c}0.0002 \\
(0.0006)\end{array}$ & $\begin{array}{l}-0.0005 \\
(0.0006)\end{array}$ & $\begin{array}{l}-0.0010 \\
(0.0006)\end{array}$ \\
\hline I.Cr.GDP & $\begin{array}{c}0.0006 \\
(0.0005)\end{array}$ & $\begin{array}{c}0.0003 \\
(0.0003)\end{array}$ & $\begin{array}{c}0.0005 \\
(0.0005)\end{array}$ & $\begin{array}{c}0.0003 \\
(0.0003)\end{array}$ & $\begin{array}{l}-0.0001 \\
(0.0004)\end{array}$ & $\begin{array}{c}-0.0008 \mathrm{a} \\
(0.0003)\end{array}$ \\
\hline CR5 & $\begin{array}{l}0.0151 a \\
(0.0025)\end{array}$ & $\begin{array}{l}0.0185 a \\
(0.0013)\end{array}$ & $\begin{array}{l}0.0153 a \\
(0.0025)\end{array}$ & $\begin{array}{l}0.0183 a \\
(0.0013)\end{array}$ & $\begin{array}{l}0.0245 a \\
(0.0026)\end{array}$ & $\begin{array}{c}0.02231 a \\
(0.0019)\end{array}$ \\
\hline $\mathrm{CR} 5 \wedge 2$ & $\begin{array}{c}-0.0001 a \\
(0.0000)\end{array}$ & $\begin{array}{r}-0.0001 a \\
(0.0000)\end{array}$ & $\begin{array}{c}-0.0001 a \\
(0.0000)\end{array}$ & $\begin{array}{c}-0.0001 a \\
(0.0000)\end{array}$ & $\begin{array}{c}-0.0002 a \\
(0.0000)\end{array}$ & $\begin{array}{r}-0.0002 a \\
(0.0000)\end{array}$ \\
\hline Size & $\begin{array}{l}0.0175 a \\
(0.0041)\end{array}$ & $\begin{array}{l}0.0110 a \\
(0.0025)\end{array}$ & $\begin{array}{l}0.0169 a \\
(0.0040)\end{array}$ & $\begin{array}{l}0.0112 a \\
(0.0026)\end{array}$ & $\begin{array}{l}0.0137 a \\
(0.0050)\end{array}$ & $\begin{array}{l}0.0188 a \\
(0.0041)\end{array}$ \\
\hline Div & $\begin{array}{l}0.1384 a \\
(0.0421)\end{array}$ & $\begin{array}{l}0.2124 a \\
(0.0336)\end{array}$ & $\begin{array}{l}0.1460 a \\
(0.0423)\end{array}$ & $\begin{array}{l}0.2221 a \\
(0.0338)\end{array}$ & $\begin{array}{l}0.1487 a \\
(0.0345)\end{array}$ & $\begin{array}{l}0.2109 a \\
(0.0334)\end{array}$ \\
\hline Tier 1 & $\begin{array}{c}0.0005 \\
(0.0007)\end{array}$ & $\begin{array}{c}0.0003 \\
(0.0005)\end{array}$ & $\begin{array}{c}0.0008 \\
(0.0007)\end{array}$ & $\begin{array}{c}0.0005 \\
(0.0005)\end{array}$ & $\begin{array}{c}0.0007 \\
(0.0007)\end{array}$ & $\begin{array}{l}-0.0001 \\
(0.0005)\end{array}$ \\
\hline ROA & $\begin{array}{l}0.0176 a \\
(0.0022)\end{array}$ & $\begin{array}{l}0.0069 a \\
(0.0019)\end{array}$ & & & & \\
\hline ROE & & & $\begin{array}{l}0.0015 a \\
(0.0002)\end{array}$ & $\begin{array}{l}0.0004 a \\
(0.0002)\end{array}$ & & \\
\hline $\mathrm{C} / \mathrm{I}$ & & & & & $\begin{array}{c}-0.0029 a \\
(0.0001)\end{array}$ & $\begin{array}{r}-0.0030 a \\
(0.0002)\end{array}$ \\
\hline $\begin{array}{l}\text { Maximum } \\
\text { point }\end{array}$ & 66.4 & 65.6 & 66.5 & 65.7 & 64.0 & 63.9 \\
\hline $\mathrm{N}$ & 605 & 705 & 601 & 702 & 625 & 727 \\
\hline
\end{tabular}

Note: $\mathrm{a}, \mathrm{b}$ and $\mathrm{c}$ represent $1 \%, 5 \%$ and $10 \%$ significance levels, respectively.

Source: Authors' estimations based on the S\&P GMI data.

domestic banks in SECE countries had already caught up with foreign banks in terms of efficient management practices or technology in the 2000s and are therefore no less competitive than foreign banks.

The diversification of the bank's income was another determinant tested in the regressions. The results show its positive impact on the profit efficiency in the entire SECE region, and separately in the EU and non-EU countries. These results are in line with Elsas, Hackethal and Holzhauser (2010) who proved that income diversification rises bank profitability and Vander Vennet (2002) who stated that divesified banks are more revenue efficient. In the case of SECE banks such positive relationship might result from the fact that larger banks take advantage of the economies of scope and provide broader spectrum of financial products, other than loans and deposits, thereby generating additional revenue streams. Non-interest bank activities are particularly important in the low interest rate environment contributing to a decline in banks' net interest income. The income from fees, commissions, financial operations or sales of insurance and investment products help banks to earn additional revenue and stabilize its financial results.

As expected, profit efficiency of banks in the entire SECE region is positively influenced by the rise of the return on assets (positive values of the ratio for ROA) and return on equity (positive values of the ratio for $\mathrm{ROE}$ ), as well as cost efficiency (negative values of the ratio for $\mathrm{C} / \mathrm{I})$. On the other hand, the improvement of capital endowment has marginal positive impact on profit efficiency, which is especially visible in non-EU countries.

Finally, macroeconomic variables affect profit efficiency in EU and non-EU countries in a different way. Higher GDP growth contributes to improved efficiency in non-EU countries (statistically significant in all tested models), while in EU member states it has 
negative impact (models $3 a$ and $3 b$ ). This can be explained by the fact that in periods of rapid economic expansion and GDP growth, banks are often more willing to take a risk and invest in projects characterised with low creditworthiness. Such a strategy usually leads to an increase in write-offs for non-performing loans and deterioration of financial results. A similar mechanism may take place in case of an excessive increase in the value of loans granted to the private sector. Negative signs for the Cr.GDP variable for the EU countries (models $3 a$ and $3 b$ ) indicate that such an expansionary strategy can be used more frequently by banks in countries with more stable banking sectors applying lower interest rates. In addition, rising inflation weakens the banks' profit efficiency, especially in EU countries.

\section{CONCLUSIONS}

This paper addresses a relatively rarely discussed problem of the impact of banking market structure on bank profit efficiency in SECE countries between 2005 and 2019.

The results of the study indicate that, in the entire SECE region, both in the EU and non-EU countries, the increase in concentration positively affects the banks' profit efficiency. This impact is similar for banks controlled by domestic and by foreign investors. The relationship is of a nonlinear nature and can be described by the equation of an inverted parabola. It means that in banking sectors, characterised by a low and high concentration, an additional growth in concentration will bring less improvement in profit efficiency than in moderately concentrated sectors. In a similar manner, an increase in the size of bank will boost the profit efficiency of banks. Such a relationship between the structure of the banking market and profit efficiency indicates that banks, both in EU and non-EU countries, operate in accordance with the efficient structure hypothesis, which assumes that more effective banks take over less effective competitors, increasing their size and, at the same time, increasing the concentration and efficiency of the entire sector. In both groups of countries, the diversification of the operating income improves the profit efficiency of banks, which is related to the use of the economies of scope and greater involvement of banks in financial operations and sales of non-banking financial products.
The parameters specific to individual banks, i.e., return on assets (ROA), return on equity (ROE) and costefficiency (C/I) have a significantly positive impact on the banks' profit efficiency in both groups of countries. Only in the case of banks from non-EU countries, capital equipment has a positive impact on profit efficiency, which may result from their more conservative investment policy and the use of lower financial leverage. Additionally, banks' profit efficiency is also favoured by greater stability of retail prices (EU countries), lower dynamics of GDP growth (non-EU countries) as well as a fall (EU countries) and a rise (non-EU countries) in the value of loans granted to the private sector in relation to GDP.

The results of this paper have a number of implications for bank supervisors and academics. The research, showing the positive impact of concentration on the efficiency of the banking sector and the space for a favourable increase in concentration which still exists in these sectors, can be taken into account in the case of issuing opinions on the authorization of a market merger of banks or the takeover of a bank at risk.

This study is not free from potential caveats. The lack of the bank-level data before 2005 prevents us from performing a more detailed analysis of the precrisis situation in the SECE banking sectors. The use of quarterly data instead of annual could help to draw a more detailed picture of the inefficiency of SECE banks. Finally, although it was not a focus of our study, the future research could also analyse the cost inefficiencies of the banks. 
Table A1. Definitions of variables

\begin{tabular}{|c|c|c|}
\hline Variable & Description & Source \\
\hline Prof & Profit: operating income & S\&P GMI \\
\hline Q1 & Output 1: gross loans & S\&P GMI \\
\hline Q2 & Output 2: other financial assets: total financial assets less gross loans & S\&P GMI \\
\hline W1 & Price of physical capital: property and equipment depreciation to fixed assets & S\&P GMI \\
\hline W2 & Price of labour: compensation and benefits expenses to total assets & S\&P GMI \\
\hline W3 & Price of funds: total interest expense to total financial liabilities & S\&P GMI \\
\hline Size & Bank size: natural logarithm of total assets & S\&P GMI \\
\hline Eq.TA & Leverage: equity to assets & S\&P GMI \\
\hline Tier1 & Capital adequacy: tier 1 capital ratio & S\&P GMI \\
\hline $\mathrm{ROA}$ & Return on assets: net profit to the average total assets & S\&P GMI \\
\hline ROE & Return on equity: net profit over the average total equity & S\&P GMI \\
\hline $\mathrm{C} / \mathrm{I}$ & Cost efficiency: operating cost to operating income & S\&P GMI \\
\hline Div & $\begin{array}{l}\text { Product diversification of operating income: } 1 \text { - sum of the squared shares net interest } \\
\text { income, net fees and commissions and income on financial operations in the bank's } \\
\text { operating profit }\end{array}$ & S\&P GMI \\
\hline CR5 & Concentration: share of five largest banks in total assets of banking sector & ECB and NCBs \\
\hline $\mathrm{HHI}$ & $\begin{array}{l}\text { Concentration: sum of the squared each bank's total assets to total assets of banking } \\
\text { sector }\end{array}$ & $\mathrm{ECB}$ and $\mathrm{NCBs}$ \\
\hline GDP.gr & Development of the economy: annual growth of gross domestic product & World Bank \\
\hline Infl & Inflation rate: annual percentage change in GDP deflator & World Bank \\
\hline Cr.GDP & Financial intermediation: domestic credit to private sector as \% of GDP & World Bank \\
\hline
\end{tabular}

Note: NCBs - national central banks.

Source: Authors' creation.

Table A2. Correlation matrix of explanatory variables

\begin{tabular}{|c|c|c|c|c|c|c|c|c|c|c|c|}
\hline & GDP.gr & Infl & CR5 & $\mathrm{HHI}$ & Cr.GDP & Size & Tier 1 & ROA & ROE & $\mathrm{C} / \mathrm{I}$ & Div \\
\hline GDP.grh & 1 & & & & & & & & & & \\
\hline Infl & $0.202^{*}$ & 1 & & & & & & & & & \\
\hline CR5 & -0.015 & $-0.179 *$ & 1 & & & & & & & & \\
\hline $\mathrm{HHI}$ & $-0.042^{*}$ & $-0.206^{*}$ & $0.681^{*}$ & 1 & & & & & & & \\
\hline Cr.GDP & $-0.450^{*}$ & $-0.237^{*}$ & $0.189^{*}$ & $0.332^{*}$ & 1 & & & & & & \\
\hline Size & 0.019 & $-0.063^{*}$ & $-0.270^{*}$ & $-0.222^{*}$ & $-0.135^{*}$ & 1 & & & & & \\
\hline Tier 1 & 0.019 & -0.036 & $0.159^{*}$ & $0.121^{*}$ & $-0.048^{*}$ & $-0.179 *$ & 1 & & & & \\
\hline ROA & $0.180^{*}$ & -0.027 & 0.034 & 0.014 & $-0.154^{*}$ & $0.080^{*}$ & $0.101^{*}$ & 1 & & & \\
\hline ROE & $0.180^{*}$ & 0.008 & -0.005 & -0.011 & $-0.176^{*}$ & $0.104^{*}$ & $0.073^{*}$ & $0.869^{*}$ & 1 & & \\
\hline $\mathrm{C} / \mathrm{I}$ & -0.010 & -0.001 & 0.025 & 0.034 & $0.105^{*}$ & $-0.299^{*}$ & -0.006 & $-0.429^{*}$ & $-0.437^{*}$ & 1 & \\
\hline Div & -0.024 & 0.006 & -0.027 & -0.006 & 0.017 & -0.020 & $0.061^{*}$ & -0.023 & $-0.045^{*}$ & 0.014 & 1 \\
\hline
\end{tabular}

Note: * represents $5 \%$ significance level.

Source: Authors' estimations based on the S\&P GMI data. 


\section{REFERENCES}

Akhavein, J., Berger, A. and Hummphrey, D. 1997. The Effects of Megamergers on Efficiency and Prices: Evidence from a Bank Profit Function. Review of Industrial Organization 12(1): 95-139. DOI:10.1023/A:1007760924829.

Altunbas, Y., Carbo, S., Gardener, E. and Molyneux, P. 2007. Examining the Relationships between Capital, Risk and Efficiency in European Banking. European Financial Management 13(1): 49-70. DOI: 10.1111/j.1468-036X.2006.00285.x.

Andries, A. and Capraru, B. 2014. The nexus between competition and efficiency: The European banking industries experience. International Business Review 23 (3): 566579. DOI: 10.1016/j.ibusrev.2013.09.004.

Andries, A. and Ursu, S. 2016. Financial crisis and bank efficiency: An empirical study of European banks. Economic Research-Ekonomska Istrazivanija 29 (1): 485-497.

Ariss, T. 2010. On the implications of market power in banking: evidence from developing countries. Journal of Banking and Finance 34 (4): 765-775.

Asaftei, G. and Kumbhakar, S. 2008. Regulation and efficiency in transition: the case of Romanian banks. Journal of Regulatory Economics 33: 253-282. DOI: 10.1007/ s11149-007-9041-0.

Asongu, S. and Odhiambo, N. 2018. Size, efficiency, market power, and economies of scale in the African banking sector. Financial Innovation 5 (4). https://doi. org/10.1186/s40854-019-0120-x.

Avramidis, P., Cabolis, Ch. and Serfes, K. 2018. Bank size and market value: The role of direct monitoring and delegation costs. Journal of Banking \& Finance 93(C): 127-138. DOI: 10.1016/j.jbankfin.2018.05.016.

Baele, L., De Jonghe, O. and Vander Vennet, R. 2007. Does the stock market value bank diversification? Journal of Banking \& Finance 31 (7): 1999-2023. https://doi. org/10.1016/j.jbankfin.2006.08.003.

Berger, A. 1995. The Profit-Structure Relationship in Banking - Tests of Market-Power and Efficient-Structure Hypotheses. Journal of Money, Credit and Banking 27 (2): 404-431. DOI: 10.2307/2077876.

Berger, A. and Hannan, T. 1998. The efficiency cost of market power in the banking industry: $A$ test of the "quiet life" and related hypotheses. Review of Economics and Statistics 80 (3): 454-465.

Berger, A. and Mester, L. 1997. Inside the black box: What explains differences in the efficiencies of financial institutions? Journal of Banking and Finance 21 (7): 895-947. http://dx.doi.org/10.1016/S0378-4266(97)00010-1.

Berger, A., Hasan, I. and Zhou, M. 2009. Bank ownership and efficiency in China: what will happen in the world's largest nation? Journal of Banking \& Finance 33 (1): 113-130.

Boyd, J. and de Nicolo, G. 2005. The theory of bank risk taking and competition revisited. The
Journal of Finance 60 (3): 1329-1343. https://doi. org/10.1111/j.1540-6261.2005.00763.x.

Casu, B. and Girardone, C. 2006. Bank competition, concentration and efficiency in the single European market. The Manchester School 74 (4): 441-468.

Chen, Ch. 2009. Bank Efficiency in Sub-Saharan African Middle Income Countries. IMF Working Paper 09/14: 1-34.

Cifter, A. 2015. Bank concentration and non-performing loans in Central and Eastern European countries. Journal of Business Economics and Management 16 (1):117-137. DOI: $10.3846 / 16111699.2012 .720590$.

Coccorese, P. and Pellecchia, A. 2010. Testing the 'quiet life' hypothesis in the Italian banking industry. Economic Notes 39 (3): 173-202. http://dx.doi. org/10.1111/j.1468-0300.2011.00227.x.

Curi, C., Lozano-Vivas, A. and Zelenyuk, V. 2015. Foreign bank diversification and efficiency prior to and during the financial crisis: Does one business model fit all? Journal of Banking \& Finance 61 (1): S22-S35. https://doi. org/10.1016/j.jbankfin.2015.04.019.

Delis, M. 2012. Bank competition, financial reform, and institutions: The importance of being developed. Journal of Development Economics 97 (2): 450-465. DOI: 10.1016/j. jdeveco.2011.05.012.

Delis, M. and Papanikolaou, N. 2009. Determinants of bank efficiency: evidence from a semi-parametric methodology. Managerial Finance 35(3): 260-275.

Delis, M. and Tsionas, E. 2009. The joint estimation of banklevel market power and efficiency. Journal of Banking \& Finance 33(10): 1842-1850. https://doi.org/10.1016/j. jbankfin.2009.04.006.

Demsetz, H. 1973. Industry structure, market rivalry, and public policy. Journal of Law and Economics 16 (1): 1-9.

Duygun, M., Sena, V. and Shaban, M. 2013. Schumpeterian competition and efficiency among commercial banks. Journal of Banking and Finance 37 (12): 5176-5185.

ECB. 2020. Financial Stability Review. May 2020. European Central Bank. Eurosystem, Frankfurt, Germany. [https://www.ecb.europa.eu/pub/pdf/fsr/ecb. fsr202005 1b75555f66.en.pdf].

Efthyvoulou, G. and Yildirim, C. 2014. Market power in CEE banking sectors and the impact of the global financial crisis. Journal of Banking and Finance 40: 11-27.

Elsas, R., Hackethal, A. and Holzhauser, M. 2010. The anatomy of bank diversification, Journal of Banking \& Finance 34: 1274-1287. https://doi.org/10.1016/j. jbankfin.2009.11.024.

Evanoff, D.D. and Israilevich, P.R. 1991. Regional differences in bank efficiency and technology. The Annals of Regional Science 25: 41-54. https://doi.org/10.1007/BF01581896.

Fang,Y., Hasan, I.and Marton, K.2011. Bankefficiencyin SouthEastern Europe: The role of ownership, market power 
and institutional development. Economics of Transition 19 (3): 495-520. DOI: 10.1111/j.1468-0351.2011.00420.x

Fries, S. and Taci, A. 2005. Cost efficiency of banks in transition: Evidence from 289 banks in 15 post-communist countries. Journal of Banking \& Finance 29: 55-81. DOI:10.1016/j.jbankfin.2004.06.016.

Fu, X. and Heffernan, S. 2009. The effects of reform on China's bank structure and performance. Journal of Banking \& Finance 33 (1): 39-52.

Fungácová, Z., Shamshur, A. and Weill, L. 2017. Does bank competition reduce cost of credit? Cross-country evidence from Europe. Journal of Banking \& Finance 83: 104120. http:// dx.doi.org/10.1016/j.jbankfin.2017.06.014.

Goldberg, L. and Rai, A. 1996. The Structure-Performance Relationship for European Banking. Journal of Banking and Finance 20 (4): 745-771.

Greene, W. 2005. Reconsidering heterogeneity in panel data estimators of the stochastic frontier model. Journal of Econometrics 126 (2): 269-303.

Hannan, T. 1991. Bank commercial loan markets and the role of market structure: evidence from surveys of commercial lending. Journal of Banking \& Finance 15 (1): 133149. https://doi.org/10.1016/0378-4266(91)90042-K.

Hicks, J. 1935. Annual survey of economic theory: The theory of monopoly. Econometrica 3 (1): 1-20. DOI:10.2307/1907343.

Kasman, A. and Yildirim, C. 2006. Cost and profit efficiencies in transition banking: the case of new EU members. Applied Economics 38: 1079-1090. https://doi. org/10.1080/00036840600639022.

Kirkpatrick, C., Murinde, V. and Tefula, M. 2008. The measurement and determinants of $x$-inefficiency in commercial banks in Sub-Saharan Africa. The European Journal of Finance 14 (7): 625-639, DOI:10.1080/13518470701705769.

Koetter, M., Vins, O. 2008. The quiet life hypothesis in banking: Evidence from German savings banks. Working Paper Series: Finance and Accounting, Fachbereich Wirtschaftswissenschaften, Goethe-Universität Frankfurt a. M. 190/2008. [http://hdl.handle.net/10419/36642].

Laeven, L. and Levine, R. 2007. Is there a diversification discount in financial conglomerates? Journal of Financial Economics 85 (2): 331-367.

Lensink, R., Meesters, A. and Naaborg, I. 2008. Bank efficiency and foreign ownership: Do good institutions matter? Journal of Banking \& Finance 32 (5): 834-844.

Loukoianova, E. 2008. Analysis of the Efficiency and Profitability of the Japanese Banking System. IMFWorking Papers 08 (63). DOI:10.5089/9781451869255.001.

Lozano-Vivas, A. and Pasiouras, F. 2010. The impact of nontraditional activities on the estimation of bank efficiency: International evidence. Journal of Banking \& Finance, 34 (7): 1436-1449.
Marquez, R. 2002. Competition, adverse selection, and information dispersion in the banking industry. Review of Financial Studies 15: 901-926.

Maudos, J. and Fernandez de Guevara, J. 2007. The cost of market power in banking: Social welfare loss vs. cost inefficiency. Journal of Banking \& Finance 31 (7): 2103-2125.

Maudos. J., Pastor, J., Perez. F. and Quesada, J. 2002. Cost and profit efficiency in European banks. Journal of International Financial Markets Institutions and Money 12 (1): 33-58. DOI:10.1016/S1042-4431(01)00051-8.

Mesa, R., Sánchez, H. and Sobrino, J. 2014. Main determinants of efficiency and implications on banking concentration in the European Union. Spanish Accounting Review 17 (1): 78-87.

Mirzaei, A., Moore, T. and Liu, G. 2013. Does market structure matter on banks' profitability and stability? Emerging vs. advanced economies. Journal of Banking \& Finance 37 (8): 2920-2937. DOI: 10.1016/j.jbankfin.2013.04.031.

Molyneux, P. and Forbes, W. 1995. Market Structure and Performance in European Banking. Journal of Applied Economics 27: 155-159. DOI:10.1080/00036849500000018.

MNB. 2020. Financial Stability Report. May 2020. The Magyar Nemzeti Bank, Budapest, Hungary. [https://www.mnb. hu/letoltes/financial-stability-report-2020-may.pdf].

NBP. 2018. Financial Stability Report. December 2018. National Bank of Poland, Warsaw, Poland. [https://www. nbp.pl/en/systemfinansowy/fsr201812.pdf].

NBP. 2020. Financial Stability Report. Special Issue: impacts of the COVID-19 pandemic. June 2020. National Bank of Poland, Warsaw, Poland [https://www.nbp.pl/en/systemfinansowy/fsr202006.pdf].

NBU. 2020. Financial Stability Report. June 2020. The National Bank of Ukraine, Kiev, Ukraine. [https://bank. gov.ua/admin_uploads/article/FSR_2020-H1_eng.pdf].

NBS. 2020. Financial Stability Report. May 2020. Narodna Banka Slovenska. Eurosystem, Bratislava, Slovakia. [https://www.nbs.sk/_img/Documents/ZAKLNBS/PUBLIK/ SFS/FSR_052020.pdf].

Nițoi, M. and Spulbar, C. 2015. An Examination of Banks' Cost Efficiency in Central and Eastern Europe. Procedia Economics and Finance 22: 544-551.

Parmeter, Ch. and Kumbhakar, S. 2014. Efficiency Analysis: A Primer on Recent Advances (Foundations and Trends in Econometrics). University of Miami, State University of New York at Binghamton, the USA.

Pasiouras, F. 2008. International evidence on the impact of regulations and supervision on banks' technical efficiency: an application of two-stage data envelopment analysis. Review of Quantitative Finance and Accounting 30: 187-223. https://doi.org/10.1007/s11156-007-0046-7.

Peng, J., Jeng, V., Wang, J. and Chen, Y. 2017. The impact of bancassurance on efficiency and profitability of banks: 
Evidence from the banking industry in Taiwan. Journal of Banking \& Finance 80: 1-13.

Peristiani, S. 1997. Do Mergers Improve the X-Efficiency and Scale Efficiency of U.S. Banks? Evidence from the 1980s. Journal of Money, Credit and Banking 29 (3): 326-337.

Pruteanu-Podpiera, A., Weill, L. and Schobert, F. 2008. Banking competition and efficiency: a micro-data analysis on the Czech banking industry. Comparative Economic Studies 50 (2): 253-273, http://dx.doi.org/10.1057/palgrave. ces.8100248.

Rhoades, S. and Rutz, R. 1982. Market power and firm risk: A test of the 'quiet life' hypothesis. Journal of Monetary Economics 9 (1): 73-85.

Saghi-Zedek, N. 2016. Product diversification and bank performance: Does ownership structure matter? Journal of Banking \& Finance 71: 154-167. http://dx.doi. org/10.1016/j.jbankfin.2016.05.003.

Schmid, M. and Walter, I. 2009. Do Financial Conglomerates Create or Destroy Economic Value? Journal of Financial Intermediation 18 (2):193-216. DOI: 10.1016/j. jfi.2008.07.002.

Shijaku, G. 2017. Does Concentration Matter for Bank Stability? Evidence from the Albanian Banking Sector. Journal of Central Banking Theory and Practice 6 (3): 67-94.
Silva, T., Guerra, S., Tabak, B. and de Castro Miranda, R. 2016. Financial networks, bank efficiency and risk-taking. Journal of Financial Stability 25 (C): 247-257.

Smirlock, M. 1985. Evidence on the (Non) Relationship between Concentration and Profitability in Banking. Journal of Money, Credit and Banking 17 (1): 69-83.

Tabak, B., Fazio, D. and Cajueiro, D. 2012. The relationship between banking market competition and risktaking: Do size and capitalization matter? Journal of Banking \& Finance 36 (12): 3366-3381. DOI: 10.1016/j. jbankfin.2012.07.022.

Vander Vennet, R. 2002. Cost and Profit Efficiency of Financial Conglomerates and Universal Banks in Europe. Journal of Money, Credit and Banking 34 (1): 254-82.

Williams, J. 2012. Efficiency and market power in Latin American banking. Journal of Financial Stability 8 (4): 263-276. DOI: 10.1016/j.jfs.2012.05.001.

Yildirim, S. and Philippatos, G. 2007. Efficiency of banks: Recent evidence from the transition economies of Europe, 1993-2000. European Journal of Finance 13: 123-143. DOI:10.1080/13518470600763687. 